\title{
Disrupting narratives of isolation: the production and circulation of ideas in Colombia about Latin America's progress, 1870-1900
}

Abstract: Colombians were not isolated during the last third of the nineteenth century. Transportation difficulties that slowed the movement of people and goods - a particularly challenging issue in the Andean region-proved less of a hindrance for the movement of ideas. Many intellectuals, seeking knowledge about Latin America's latest progress, worked diligently to promote the spread and understanding of global ideas among fellow Colombians. They looked to learn from republics in the region, with whom they also developed mutually beneficial intellectual and material relationships. Colombian intellectuals, many of whom played a decisive role in diplomatic postings abroad, facilitated this circulation of ideas within Colombia.

Keywords: transnational history, circulation of ideas, networks, intellectuals, diplomats.

\section{Interrumpiendo narrativas de aislamiento: la producción y circulación de ideas del progreso de América Latina en Colombia, 1870-1900}

Resumen: Los colombianos no estuvieron aislados durante el último tercio del siglo XIX. Los obstáculos al transporte que frenaron el movimiento de personas y bienes, particularmente desafiantes en la región andina, fueron menos onerosos para el movimiento de ideas. Muchos intelectuales, con el objetivo de asimilar las señales de progreso de América Latina, trabajaron diligentemente para promover la circulación y la comprensión de las ideas globales por parte de los colombianos. Ellos observaron a las repúblicas vecinas para aprender de ellas y con ellas, desarrollando una variedad de relaciones intelectuales y materiales provechosas. Los intelectuales colombianos, muchos de los cuales desempeñaron un papel decisivo al asumir misiones diplomáticas en el extranjero, facilitaron esta circulación de ideas dentro de Colombia.

Palabras clave: historia transnacional, circulación de ideas, redes, intelectuales, diplomáticos.

\section{Questionando narrativas de isolamento: produção e circulação de ideias sobre o progresso da América Latina na Colômbia, 1870-1900}

Resumo: Os colombianos não estiveram isolados durante o último terço do século XIX. Dificuldades de transporte que retardavam o movimento de pessoas e bens, particularmente desafiadoras na região andina, ofereceram menos obstáculos para o movimento de ideias. Muitos intelectuais, em busca de conhecimento sobre os últimos progressos na América Latina, trabalharam diligentemente para promover a difusão e a compreensão de ideias globais entre colegas colombianos. Tentaram aprender com as repúblicas vizinhas, com as quais desenvolveram relações de trocas intelectuais e materiais proveitosas. Intelectuais colombianos, muitos dos quais exerceram um papel decisivo em postos diplomáticos no exterior, facilitaram essa circulação de ideias dentro da Colômbia.

Palavras-chave: história transnacional, circulação de ideias, redes, intelectuais, diplomatas.

Cómo citar este artículo: Jairo Campuzano-Hoyos, "Disrupting narratives of isolation: the production and circulation of ideas in Colombia about Latin America’s progress, 1870-1900", Trashumante. Revista Americana de Historia Social 17 [2021]: 126-149.

DOI: 10.17533/udea.trahs.n17a06

Fecha de recepción: 11 de marzo de 2020

Fecha de aprobación: 13 de agosto de 2020

Jairo Campuzano-Hoyos: Doctor en Historia por la Universidad de Notre Dame. Profesor titular y coordinador del Grupo de Investigación en Historia Empresarial de la Universidad Eafit. ORCID: 00000002-7887-4491.

. Correo electrónico: jcampuz2@eafit.edu.co 


\section{Disrupting narratives of isolation: the production and circulation of ideas in Colombia about Latin America's progress, $1870-1900^{\star}$}

Jairo Campuzano-Hoyos

\section{Introduction}

n 1939, brothers Julio and Víctor E. Caro visited Tomás Rueda Vásquez, director of Bogotás National Library, to donate 2,365 volumes that their father, the renowned Colombian intellectual and politician Miguel Antonio Caro (18431909), had carefully put together and treasured in his personal collection over decades. ${ }^{1}$ Ever since, the Library has held a special collection named after their father. Paradoxically, at a time when Colombia was allegedly "isolated"-most Colombians lived mainly in the interior highlands, according to most works of historiography-Miguel Antonio Caro managed to collect hundreds of printed works from around the world despite never having traveled outside Bogotá and its surrounding areas. ${ }^{2}$ How he achieved this is a valid question.

* This article is an adaptation of chapter 3 of my doctoral dissertation entitled "The Quest for Material Progress in Global Perspective: Colombia 1840s-1900s" (University of Notre Dame, 2018). I thank Universidad Eafit, Colciencias, and Fulbright in Colombia, the Department of History, and the Kellogg Institute for International Studies of the University of Notre Dame in the United States, and Bielefeld University's Graduate School of History and Sociology (BGHS) in Germany for their financial and institutional support while conducting my doctoral research and writing. An earlier version of this paper was presented at the 2019 annual meeting of the Business History Conference. I thank Anne Hanley for her useful comments and advises. My particular gratitude goes to Ted Beatty in Notre Dame and to my friends Diana Londoño Correa and Juan Carlos López Díez, who read several drafts of this paper and provided insightful discussions.

1. Álvaro Rodríguez Torres, Reseña histórica de la Biblioteca Nacional de Colombia (Bogotá: Colcultura, 1994) 8; Asociación de Bibliotecas Nacionales de Iberoamérica, coord. Historia de las bibliotecas nacionales de Iberoamérica: pasado y presente (Mexico City: Universidad Nacional Autónoma de México, 1995) 87.

2. Rafael Rubiano Muñoz, Prensa y tradición: La imagen de España en la obra de Miguel Antonio Caro (Medellín: Siglo del Hombre, 2011) 174. 
Miguel Antonio Caro was a highly-regarded philologist, whose influential works reached a wide readership in Europe and the Americas. ${ }^{3}$ Over the course of his life he created an intense exchange of ideas with many fellow local and foreign intellectuals, forming an extensive network in which he was a lively contributor, by debating and commenting on the world's current events and with his extensive collection of books. As an illustrative case, during the 1870s Caro cultivated a warm friendship with renowned Argentinian intellectual Juan María Gutiérrez and exchanged printed materials with him—such as Caro's 1873 Obras de Virgilio traducidas en versos castellanos, which he sent to Gutiérrez in Buenos Aires in late $1874 .{ }^{4}$ Although they complained about their trouble accessing printed materials within Latin America, both Caro and Gutiérrez managed to obtain what they wanted because they were "hungry" for Latin American publications, as they openly declared in their correspondence. ${ }^{5}$ They were able to overcome difficulties by shipping books and printed materials between Argentina and Colombia via France and the United States, with the intermediation of friends in common and relatives such as Colombian scientist Ezequiel Uricoechea in Paris, and Caro's brother-in-law Roberto de Narváez in New York. ${ }^{6}$ The Pacific provided an alternative route. As Gutiérrez wrote in a letter dated September 1875, "being rector of the University [of Buenos Aires], I sent and arrived in Bogotá a batch of books, almost all official and administrative, receiving in exchange another batch of the same kind. This makes me presume," Gutiérrez stressed, "that it is not impossible for you to have a box of Argentine publications that I start to form tomorrow and that will go via the vapors of the Pacific through my bookseller Dn. Carlos Casavalle."7 Such exchanges helped Miguel Antonio Caro and several other intellectuals to build their personal libraries. Fortunately, in Colombia and elsewhere, ideas could circulate with greater ease and freedom than was possible for people. They often followed long-established trade routes across the Americas; in the same way goods were exchanged, ideas could also circulate.

Many Latin Americans were intellectually connected during the second half of the nineteenth century. Transportation difficulties that slowed the movement of people and goods - a particularly challenging issue in the Andean region-proved less of a hindrance for the movement of ideas. To overcome these problems, some people like Miguel Antonio Caro and Juan María Gutiérrez used intermediaries in the Atlantic basin's main hubs. Such a route was traditionally assumed to correspond to North Atlantic exchanges, rather than Latin American ones. However, similarly to some Colombian exports, which had to pass through ports such

3. Pedro Henríquez Ureña, Historia cultural y literaria de la América Hispánica (Madrid:Verbum, 2006) 336.

4. Guillermo L. Guitarte, ed., Cartas desconocidas de Miguel Antonio Caro, Juan María Gutiérrez, y Ezequiel Uricoechea (Bogotá: Instituto Caro y Cuervo, 1962) 18, 29-38.

5. Guitarte 29.

6. Guitarte 31-32, 37-38, 41-42, 50, 53-54, 56, 74.

7. Guitarte 37. All translations from documents and newspapers are from the author. 
as Hamburg before reaching Latin American ports like Valparaíso in Chile during the early 1870s, mutual Latin American exchanges required a degree of intermediation because the contemporary infrastructure did not provide better alternatives. ${ }^{8}$ Exchanges often involved long distances and complex logistics but nevertheless Colombians were not isolated, and they were able to connect with other Latin Americans during the second half of the nineteenth century. Although historiography has largely overlooked interactions between Colombia and other Latin American countries, Colombians looked to learn from republics in the region, with whom they also developed mutually beneficial intellectual and material relationships. International observers also analyzed Colombia, but this article does not focus on these connections.

The historiography of the nineteenth century has traditionally argued that Latin Americans in general, and Colombians in particular, exclusively looked for models (or points of reference) in the North Atlantic. ${ }^{9}$ For statesmen and interested citizens in Colombia and elsewhere in the Western world during the nineteenth century, North Atlantic developments were undeniably important. Colombians had maintained political, economic, and intellectual relations with the North Atlantic for centuries. Thus, the conventional understanding that several nineteenth-century Colombians embodied European models and values and developed them further is neither new nor fully satisfactory when trying to understand the history of nineteenth-century Colombia. Intra-Latin American values and interactions also shaped hemispheric developments. Some historians, such as Colombia’s Germán Colmenares and Spain's Josep Barnadas, pointed this out in the late 1980s, but otherwise Colombia's history within wider hemispheric contexts has been largely ignored. ${ }^{10}$ Relatively recent contributions on international relations as well as on the construction and dissemination of national and Latin or Hispanic American identities have begun to take note of the role such values and interactions played in shaping nineteenth-century Latin America. ${ }^{11}$

8. Estadística comercial de la República de Chile correspondiente al año de 1873 (Valparaíso: Imprenta del Mercurio, 1874) xxi.

9. Mauricio Tenorio-Trillo, Mexico at the World's Fairs: Crafting a Modern Nation (Berkeley: University of California Press, 1996); Frédéric Martínez, El nacionalismo cosmopolita: la referencia europea en la construcción nacional en Colombia, 1845-1900 (Bogotá: Banco de la República / Instituto Francés de Estudios Andinos, 2001); Matthew C. Mirow, Latin American Law. A History of Private Law and Institutions in Spanish America (Austin: University of Texas Press, 2004); Juan Maiguashca, "Historians in Spanish South America: Cross-References Between Centre and Periphery," The Oxford History of Historical Writing. 1800-1945, vol. 4, ed. Stuart Macintyre and others (Oxford: Oxford University Press, 2011) 463-487. An interesting exception is Teresa Cribelli's recent contribution:Teresa Cribelli, Industrial Forests and Mechanical Marvels: Modernization in NineteenthCentury Brazil (New York: Cambridge University Press, 2016).

10. Maiguashca 464-466.

11. Ori Preuss and Juan Pablo Scarfi, "Relaciones internacionales, identidades colectivas y vida intelectual en América Latina, 1810-1945: Presentación,” Revista Complutense de Historia de América 39 (2013): 19. 
If historiography suggests that no international interactions have played a noteworthy role in the making of Colombia's political, economic, and cultural spheres other than those with the North Atlantic, it is partially because the Atlantic basin was the assumed environment where formal, visible exchanges took place for centuries. Yet crucial aspects of Colombia's history are to be found outside obvious areas such as legal transactions, successful economic relations, public (and publicized) exchanges, and formalized interactions. Some silences and unseen interactions were paramount. Although international trade records and other quantifiable data suggest that Colombia's economy was clearly geared toward the North Atlantic up until 1930, diplomatic documents as well as periodicals and a variety of official and personal memoirs reveal much wider exchanges and orientations. Therefore, in the collective imaginary of nineteenth-century Colombia, representations of Latin American countries became regularly vivid because of their increasing exposure-directly or indirectly - to printed works from around the world, many delving into the history of Latin American countries and showing their own signs of progress. Via the printed word, information circulated about Latin America as well as other countries, often reaching literary circles, tertulias (informal social gatherings), partisan societies, and artisan guilds in the form of periodicals, maps, illustrations, and books. It also spread through gossip and public-speaking events, a customary means at that time for reaching the illiterate and low-income population in both urban and rural areas. ${ }^{12}$

After researching the whereabouts, networks, and official duties of some intellectuals, I argue that many interested Colombians worked diligently on promoting the circulation and understanding of global ideas among their fellow countrymen. They fueled images of correspondence and expectations of mutual learning among Latin Americans, disrupting the conventional narratives of isolation and mental orientations restricted to the North Atlantic in nineteenth-century Colombia. These intellectuals aimed to provide their compatriots with the reliable means for acquiring knowledge of Latin American countries' signs of progress, and to gauge Colombia's relative place within the region. In nineteenth-century Latin America, "progress" would simultaneously become a commonplace concept (a continuous, forward movement toward improvement) and an eloquent expression of how populations determined their place in the world.

This article is divided into three parts. Firstly, it briefly highlights Colombians' wide-ranging interconnections via the printed word. I argue that geographic and infrastructural restrictions did not constrain the movement of global ideas in Colombia, particularly after custom of canjes (the exchange of publications) had become official and widespread. Building on the idea of connection rather than isolation,

12. Patricia Londoño-Vega, Religion, Culture, and Society in Colombia: Medellín and Antioquia, 18501930 (Oxford: Oxford University Press, 2002) 218-235; Martínez 73-74; Frank Safford and Marco Palacios, Colombia: Fragmented Land, Divided Society (New York: Oxford University Press, 2002) 160; Gilberto Loaiza Cano, Poder letrado: Ensayos sobre historia intelectual de Colombia, siglos XIX y XX (Cali: Universidad del Valle, 2014) 87-92. 
the following two parts examine the experiences of some Colombian intellectuals and diplomats who adapted useful ideas from abroad for the benefit of their fellow Colombians. The second part analyzes different diplomatic missions in the Southern Cone, showing how Colombia's diplomatic corps paved the way for the exchange of knowledge by signing conventions and promoting the flow of scientific and literary works, official documents, and statistics. They also made their own observations of - and learned lessons from-other countries that were showed evident signs of progress, such as Chile and Argentina. The third part examines the role played by some Latin American intellectuals in Paris, the so-called "capital of Latin America." It focuses mainly on Colombians who actively helped create associations, specialized libraries, and periodicals, enhancing the circulation of knowledge about Latin American countries' past and contemporary history in Colombia. In this final part Paris springs as a major global hub for Latin Americans. Colombian intellectuals took advantage of this and successfully gathered and selected useful ideas and printed materials and disseminated them in their home country. These three scenarios provide an outline but do not tell us the whole story. However, by illustrating a fraction of a global movement this article confirms the genuine and continued commitment of some Colombians to provide their compatriots with the intellectual means to assess Colombia's place in the world and to conceive their own project of material progress toward the end of the nineteenth century. This article contributes to an emerging literature on Latin American intellectuals as diplomats such as the recent dossier edited by Carlos Marichal and Alexandra Pita. ${ }^{13}$

\section{Relativizing Colombia's "isolation"}

Aided by the improvement of steamship navigation from the 1860s and by the expansion of telegraph lines since the 1870s, which interconnected the world to an unprecedented degree, some Colombians played a major role in the circulation of global goods and ideas. ${ }^{14}$ Infrastructure developments in Colombia's ports as well as in the Isthmus of Panama (for example, the interoceanic railroad inaugurated in 1855) improved this circulation. ${ }^{15}$ In the fiscal year 1869-1870, Colombians imported roughly 85 tons of paper and publications to circulate ideas and useful knowledge in their country, an amount equivalent to the same year's imports of hoes, axes, shovels, machetes, and limes combined - to mention only the legal trade through the customs houses of

13. Carlos Marichal and Alexandra Pita, "Algunas reflexiones sobre la historia de los intelectuales/diplomáticos latinoamericanos en los siglos XIX y XX: Introducción al dossier Intelectuales y diplomacia en América Latina," Revista de Historia de América 156 (2019): 97-123. DOI: 10.35424/rha.156.2019.235.

14. Daniel Emilio Rojas, "Los latinoamericanos de París en el cambio de siglo. Sobre Die Hauptstadt Lateinamerikas (2013), de Jens Streckert," Colombia Internacional 87 (2016): 244. DOI: 10.7440/ colombiaint87.2016.10.

15. Ernesto de Jesús Castillero Reyes, El Ferrocarril de Panamá y su historia (Panama: Imprenta Nacional, 1932) 22-25. 
Buenaventura and Tumaco on the Pacific coast; Cartagena, Sabanilla, Santa Marta, and Riohacha on the Atlantic coast, and Cucuta, the inland border crossing with Venezuela. Colombia imported 50 tons of printing paper, mostly destined for publishing houses and public offices, as well as 505 pounds of newspapers, 778 pounds of maps, 1.3 tons of booklets, and 32.7 tons of printed books, mostly from Colon, Grimsby, Hamburg, Havana, Jamaica, Le Havre, Liverpool, Maracaibo, Paris, and Saint Thomas. Many of these printed materials could have been Latin American publications, yet the unavoidable levels of intermediation made it difficult to trace their origin. ${ }^{16}$ In other words, roughly 8,000 copies of six-page newspapers (14.0 by 22.5 inches) and 46,000 copies of 400 -page books ( 5.6 by 8.5 inches) could have entered Colombia via customs that year. Therefore, these and other imports may have reached directly or indirectly (though not with an even distribution) many of Colombia's 796 pueblos (small towns), 77 villages, 66 cities, 22 aldeas (small villages), 8 districts, 6 caseríos (hamlets), and 2 islands included in a guide of distances between each of those places and Bogotá in 1890.This record attests to the existence of as many settlements as trade routes, regardless of their importance, and it is worth noting that this book of distances was the second and expanded edition of the same work first published in $1870 .{ }^{17}$ The amount of imported printing paper, the number of publications, and this list of settlements and their distances from Bogotá, all provide solid evidence of a ground already prepared for the circulation of global ideas in Colombia toward the end of the nineteenth century.

Panama was part of Colombia until 1903. Strategically located, it was vital for bringing goods and ideas from all over the world to Colombia's principal ports, where imports like printing paper, books, booklets, maps, and newspapers were distributed along with local publications - some of which republished excerpts from foreign works - to urban, suburban, and rural hubs. In 1891, a Canadian traveler in Panama, Wolfred Nelson, reported that seven regular shipping lines on the Atlantic side of the Isthmus and three on the Pacific side connected with it. They included a "new South American line that has just inaugurated a regular service between the Isthmus, Ecuador, Peru, and Valparaíso," across the Pacific, and the Royal Mail Steam Packet Company, which had "an immense service, for their steam lines connect the Isthmus of Panama with ports in Colombia,Venezuela, the West Indian Islands, and Southampton," across the Atlantic. ${ }^{18}$ Although both the Pacific and Atlantic Oceans were natural bridges, rather than impassable divides, over which Colombians circulated ideas, canjes were perhaps the most effective way for introducing useful knowledge about Latin America to Colombia.

Colombian intellectuals fostered official and informal canjes among Latin American governments and periodical publications, especially from the late 1860s. A

16. Estadística del comercio exterior $i$ de cabotaje $i$ de los demás ramos relacionados con la hacienda nacional, correspondiente al año de 1869 a 1870 (Bogotá: Imprenta de Gaitán, 1871).

17. Manuel María Paz, Itinerario general de distancias acompañado de varios datos geográficos y de un mapa de la República de Colombia (Paris: A. Lahure, 1890).

18. Wolfred Nelson, Five Years at Panama:The Trans-Isthmian Canal (London: Sampson Low, Marston, Searle \& Rivington, 1891) 136. 
decree of 23 January 1868 ordered the establishment of the "Colombia's National Library a central office of canjes of national publications with those of the other countries of America."This office was set up primarily for the exchange of scientific and literary works, as "the most effective means of developing among the American sections their illustration and progress," as Colombia's minister of foreign affairs, Santiago Pérez Manosalva, communicated to his Chilean counterpart in 1869. ${ }^{19}$ In fact, Colombia's National Library's director José María Quijano Otero (1836-1883) wrote an introductory note expressing that "it is already felt, Sir, the need for permanent literary relations between the peoples of the American family. Linked by the community of race, religion, language, glories and even misfortunes, we hardly know each other." The full note was intended to accompany every single shipment of Colombia's collections to American countries' libraries, and indicated that Colombia's Administrador de Hacienda (the country's tax administration office) would make the actual exchange of printed materials with consuls residing in both Panama and Santa Marta, which at the time were the main hubs of Colombia's international affairs. The canjes began operation in 1870, as its director reported that, besides sending Colombia's official publications "to each of the libraries of the continent's nations," he had established an official exchange with the Smithsonian Institution in Washington and the University of Buenos Aires in Argentina, whose rector was Juan María Gutiérrez. ${ }^{20}$ Shipments to Colombia from Latin America were not delayed considerably. In 1875, Mexico's vice-consul in Panama received a box with "a beautiful collection of printed materials," such as publications related to public finances as well as education and a "magnificent geographical chart of Colombia"; he reported that, in exchange, Mexico's president had agreed to make "a collection of official publications [published] since the fall of the so-called [second] empire," (under the second French invasion from 1861 to 1867) and to send it to Colombia via Acapulco and Panama in four boxes. ${ }^{21}$ The University of Buenos Aires also sent books to Colombia in 1875, as mentioned earlier. However, the Colombian National Library was not alone in promoting official intra-Latin American canjes.

In 1876, Colombian statesman Rafael Rocha Gutiérrez, then head of Colombia's office of statistics wrote to the Secretary of Finance and Development,

19. AGN, Bogotá, Ministerio de Relaciones Exteriores, Diplomática y Consular, Correspondencia del Gobierno de Chile con el de la Nueva Granada. 1824-1881, caja 212, carpeta 208, 96-97; Memoria del Secretario de lo Interior i Relaciones Esteriores al Congreso Nacional de 1872 (Bogotá: Imprenta de Medardo Rivas, 1872) 3-6.

20. Memoria del Secretario de lo Interior i Relaciones Esteriores al Congreso de Colombia (Bogotá: Imprenta de Medardo Rivas, 1870) 5-6.

21. AGN, Bogotá, Ministerio de Relaciones Exteriores, Diplomática y Consular, Correspondencia del Gobierno de México, 1824-1899, caja 650, carpeta 139, ff. 84-84v; Douglas W. Richmond, Conflict and Carnage in Yucatán: Liberals, the Second Empire, and Maya Revolutionaries, 1855-1876 (Tuscaloosa: University of Alabama Press, 2015). 
emphasizing the importance of establishing official canjes with Latin America's analogous offices. In a letter dated 15 January 1876, he stated that:

For some years, South American nations have been working perseveringly to draw up statistics to publicize the structure of their government, their resources, and their wealth; and they have published some interesting works. In Colombia we have received only the statistical works of Chile,Venezuela, and Buenos Aires; but in the former we have seen that mention is made of those statistical works of Peru, Brazil, Bolivia, Uruguay, and Ecuador. Some of them, such as Chile's commercial statistics for 1873, are equal to the most perfect works of this kind published by the governments of Europe.

With the consent of the executive branch, and through the Ministry of Foreign Affairs, I will propose a canje of statistical publications with all American nations, and with special care I will draw up comparative American statistics to measure the industrial development and the progress of the New World. ${ }^{22}$

Colombian intellectuals and officeholders perceived their country's place in the world by comparison to developments in neighboring countries; thus, by circulating official documents and statistics they could assess their achievements-or how far they still had to go-in the race for progress. While donations and official canjes would enrich Colombia's National Library and government departments like the National Statistics Office, informal canjes between Colombian and foreign periodicals would make useful information from around the world available to Colombians all across the country.

During the late nineteenth century, besides delegates shipping publications from countries in the region to the Colombian government, many periodicals established direct canjes with Colombian, in the Americas, and (a few) European counterparts, enriching the circulation of ideas among Latin Americans and contributing to creating appropriate models adapted to Colombia's particular circumstances. As an illustrative case, the number of publication exchanges involving periodicals like Bogotá's Anales de Jusrisprudencia - the organ of Colombia's Jurisprudence Society-reveals not only its far-reaching national impact, but also exemplifies the greater interest and wider orientations of some Colombians toward mutual Latin American interactions. During its first year of circulation (1896-1897) the Anales de Jusrisprudencia established canjes with 75 periodicals from 20 different Colombian cities and with 29 international publications, most of which came from Latin American countries - except for one from France and two from Spain. ${ }^{23}$ By 1904 the Society stated that its official organ had received from, and sent publications to, "Spain, Chile, Argentina,Venezuela, Central America, Cuba, Ecuador, Peru, and

22. Oficina de Estadística Nacional, Estadística de Colombia (Bogotá: Imprenta de Medardo Rivas, 1876) ii.

23. "Periódicos," Anales de Jurisprudencia. Órgano de la Sociedad Colombiana de Jurisprudencia (Bogotá) October 1896: 95-96; “Canjes," Anales de Jurisprudencia. Órgano de la Sociedad Colombiana de Jurisprudencia (Bogotá) January and February 1897: 252; "Canjes," Anales de Jurisprudencia. Órgano de la Sociedad Colombiana de Jurisprudencia (Bogotá) March and April 1897: 312. 
Uruguay." ${ }^{24}$ Likewise, when in early 1890 the influential New York periodical Scientific American launched its Spanish edition entitled La América Científica e Industrial (1890-1908), the editors of the Colombian periodical Colombia Ilustrada acknowledged receipt of its first issue less than two months after its original publication in New York. ${ }^{25}$ Colombian entrepreneur Amaranto Jaspe, who resided in Cartagena, distributed this journal in Colombia. ${ }^{26}$ The English version of the magazine, as well as its Spanish edition, contained perhaps the most comprehensive information available in Latin America about the latest scientific knowledge, industrial developments, and patent systems. Although short-lived and inconsistently delivered in general, Colombian periodicals republished news excerpts of different printed materials from Latin American countries and hubs such as New York and Paris and which the editors considered noteworthy and, more importantly, useful for Colombian contemporary needs. This was in part possible because some interested Colombians fostered the circulation of ideas by promoting official as well as informal canjes of global publications.

Intellectuals frequently had access to primary data such as statistics, laws, and official reports, as well as to narratives of all sorts that they would select and partially re-publish or summarize in personal writings. Before any Colombian had the opportunity to read local periodicals (like the widely-read El Catolicismo that came out in 1849), editors had already gone through dozens of international publications and selected what they believed was useful to their audience-and to further their own agendas. Nineteenth-century publications circulated widely within Colombia with relative ease, despite understandable infrastructure limitations. They reached public as well as private offices and libraries. Therefore, Colombians increasingly had access to a myriad of useful materials carrying new ideas, many of them appealing as part of the global race for progress. For example, the comparison between Argentina and Colombia that El Catolicismo drew in its section of foreign news in 1860 reads as follows: "The Argentine Republic has electric telegraphs and several railroads, all under construction, and many other public works of infrastructure that we lack completely." 27 If canjes with Latin American periodicals - printed both within the continent and overseas-provided perspectives on the region's own history, current events, and projects for progress, canjes with US periodicals would give Colombians access both to the ideas on the magnitude of the technology spillover from the North Atlantic to Latin American countries and to US perspectives on Latin America. Colombian intellectuals, many of whom played a decisive role during diplomatic postings abroad, facilitated this circulation of ideas within Colombia.

24. "Biblioteca," Anales de Jurisprudencia. Órgano de la Sociedad Colombiana de Jurisprudencia (Bogotá) July 1904: 264

25. "Nuevo colega Neoyorkino en castellano," Colombia Ilustrada (Bogotá) March 15, 1890: 174.

26. Jorge Alberto Restrepo and Manuel Rodríguez, "La actividad comercial y el grupo de comerciantes de Cartagena a fines del siglo XIX," Estudios Sociales 1.1 (1986): 95.

27. "República Arjentina,” El Catolicismo (Bogotá) July 24, 1860: 459. 


\section{Connecting to the Southern Cone}

Widely known for his novel María (1867), "probably the most popular nineteenth-century novel in Latin America," Colombian writer Jorge Isaacs (1837-1895) was appointed as General Consul of Colombia in Santiago (Chile) from 1870 to $1872 .^{28}$ His purpose was explicitly "to foment commerce of our Pacific coast with Chile." ${ }^{29}$ Isaacs was eager and openly optimistic about the opportunities that the Colombian state of Cauca, his homeland, would be presented with by establishing a trade route over the Pacific. Once in Santiago, he wrote long manuscripts analyzing Chile's general situation, studying the possibilities of establishing regular and promising commercial relations with this southern neighbor, and drawing up suitable models for Colombia's particular circumstances.

Jorge Isaacs was a man of letters who saw the need for a broad and historical perspective. Along with promoting official conventions and business-related knowledge, Isaacs advocated a more practical, thoughtful understanding of Chile's past and present. "It is necessary to study the history of material progress enjoyed by this republic [Chile]," Isaacs wrote in a letter introducing the Postal Convention proposal he drafted in 1871. "It is necessary to follow [Chile] step by step from 1848 to the present, and not to lose sight of it in the future in order to take advantage of its teachings and to avoid its mistakes." Having analyzed the Southern Cone's recent history, markets, and political conditions, Isaacs suggested that Colombia's longed-for material progress could build on this analysis of Chile's experienceand that of other South American countries like Argentina. Regarding the latter, Jorge Isaacs wrote in 1871: "four to five months in residence in the Argentine Republic would suffice. [...] The importance of its remarkable progress in six years, the effectiveness of federal institutions there; the flow of immigration that it has managed to attract [has] increased yearly; [...] its public education; everything encourages me to believe that my journey of a few months to that republic will be beneficial." ${ }^{30}$ By then, Chile and Argentina had already developed not only trends of increasing economic growth, but also a large body of historical research and publications equally available to locals and foreigners. ${ }^{31}$

In a period of roughly two years, Jorge Isaacs managed to study, broadcast, and advertise the potential benefits for both Colombia and Chile with trade and wider relations. In September 1871, he boasted that, in terms of fostering commerce between Colombia and Chile, "the difficulties I was able to overcome, are overcome."32 Isaacs

28. Doris Sommer, Foundational Fictions: The National Romances of Latin America (Berkeley / London: University of California Press, 1991) 172.

29. Memoria del Secretario de lo Interior i Relaciones Esteriores al Congreso de Colombia (Bogotá: Imprenta de Medardo Rivas, 1871) 52.

30. AGN, Bogotá, Ministerio de Relaciones Exteriores, Diplomática y Consular, Transferencia 2, Consulado de Colombia en Chile, 1862-1871, t. 37, ff. 23-24. Underlined in the original.

31. Maiguashca.

32. AGN, Bogotá, Ministerio de Relaciones Exteriores, Diplomática y Consular, Transferencia 2, 
also managed to elaborate a protocol on the exchange of scientific and literary publications between the two countries, which was eventually approved by Colombian Law 99 of $1873 .{ }^{33}$ In so doing, he cleared the path for more Colombians to come with an active interest in learning from Chile's experiences. In fact, apart from developing both the postal and consular conventions, Isaacs believed that the circulation of scientific and literary knowledge was critical if Colombia was to learn from countries like Chile. He also saw the importance of models that were adaptable to Colombia's particular circumstances, a conviction shared by some of his contemporaries.

In 1883, the Colombian diplomat and highly influential intellectual José María Samper (1828-1888) announced in the Colombian newspaper El Conservador that, traveling to Chile and the Argentine Republic, he wished

to take advantage of my trip in the service of the letters and sciences of those republics and of our republic, and to that end I intend to take a donation in the name of the Colombian writers to the national libraries of Santiago and Buenos Aires of the works published in Colombia; and then bring and donate to the National Library of Bogotá as many [Latin] American books as I can procure in Chile, the Argentine Republic, Montevideo, etc. ${ }^{34}$

Moreover, after reaching the Southern Cone, in 1885 Samper would signalong with representatives of Chile, Uruguay, and Argentina-a "Latin American Convention on promoting and disseminating useful publications" to promote mutual cooperation between the region's more southerly countries and Colombia. ${ }^{35}$ Thanks to such individual initiatives and official accomplishments, in 1888 Colombia's National Library received "from the Ministry of Public Education, 61 newspaper collections, all incomplete, from Venezuela, Mexico, Argentina, Ecuador, Peru, Chile, Bolivia, Brazil, Uruguay, Santo Domingo, Cuba, Curaçao, the Philippines, Jamaica, Central America, France, Italy, and Austria." ${ }^{36}$ Samper's visit to Chile and Argentina contributed substantially to the circulation of global ideas and first-hand knowledge about Latin American countries in Colombia. It also helped raise awareness of the importance of diplomacy as a means of strengthening intellectual relations and exchanges between Colombia and the wider region, which might have contributed to keeping this office in Argentina in the late 1880s.

Consulado de Colombia en Chile, 1862-1871, t. 37, f. 38v.

33. AGN, Bogotá, Ministerio de Relaciones Exteriores, Diplomática y Consular, Transferencia 2, Consulado de Colombia en Chile, 1872, t. 41, ff. 13-13v; Antonio José Uribe, ed., Anales diplomáticos y consulares de Colombia, vol. 2 (Bogotá: Imprenta Nacional, 1901) 114.

34. José María Samper, "De interés general. A los escritores colombianos," El Conservador (Bogotá) May 26, 1883: 1019.

35. Memoria del Secretario de Relaciones Exteriores dirigida al presidente de la Unión para el Congreso de 1885 (Bogotá: Imprenta de Vapor de Zalamea Hermanos, 1885) 15.

36. José Rivas Groot, "Biblioteca Nacional. Lista de las publicaciones recibidas en este establecimiento en el período transcurrido desde el $1 .^{\circ}$ de Abril hasta la fecha," Anales de la Instrucción Pública en los Estados Unidos de Colombia (Bogotá) December 1888: 518. 
In May 1888, Colombian intellectual and politician Antonio Samper was appointed General Consul in Buenos Aires. ${ }^{37}$ Having studied this country for over two years, in 1890 he wrote a long report with a detailed account on a wide range of Argentina's current affairs, such as its politics, commerce, and the "causes of Argentina's progress." ${ }^{38}$ Samper believed that Argentina was exemplary in many aspects, mainly in the way Argentinians encouraged immigration from Europe. In fact, he stated that Argentina "owes its rapid development to the external impulse that immigration provides." 39 Through detailed, specific guidelines, Samper suggested ways to promote European migration to Colombia, based on Argentina's methods and warned about the need to consider topographic, cultural, and climatic differences between Colombia and Argentina before establishing immigration policies. ${ }^{40}$ His report became of interest not only to Colombian officials but also to Argentinians themselves, who published it in 1891 because, as the introductory page states, "it is extremely interesting and contains valuable data, which can be used by the government, by our businessmen, and by agricultural entrepreneurs." ${ }^{41}$ Besides this useful document, in 1892 Samper reported the shipment of a dozen Argentinian official volumes, via Paris, to Bogotá. In a letter to the Colombian Minister of Foreign Affairs, Samper wrote that "I have sent the statistical publications that I have been able to gather directly to the Ministry of Development through the trading house of Mr. Antonio Samper and Company in Paris [his own company], to ensure their safe delivery." He also reported that Alberto B. Martínez, then General Director of Municipal Statistics of Buenos Aires, had "given the necessary instructions so that all the publications published by the Statistical Office can be sent to this consulate." ${ }^{42}$ Through the shipment of these printed materials, Samper aimed to provide Colombians with a closer look at Argentina's methods for producing enviable patterns of economic growth. By then, Argentina figured as the front runner in the race for progress in Latin America.

Antonio Samper also drew different lessons about Argentina's economic crisis during the late 1880s, a situation that led to the internationally known Baring crisis of $1890 .^{43}$ Samper, as well as several interested Colombians, had been examining

37. AHCA, Buenos Aires, Diplomática y Consular, Consulado General de Colombia, caja 444, 1890, ff. 13-13v.

38. AHCA, Buenos Aires, Diplomática y Consular, Consulado General de Colombia, caja 444, 1890, ff. $52 \mathrm{v}-53$.

39. AHCA, Buenos Aires, Diplomática y Consular, Consulado General de Colombia, caja 444, 1890, f. $53 \mathrm{v}$.

40. AHCA, Buenos Aires, Diplomática y Consular, Consulado General de Colombia, caja 444, 1890, ff. $53 \mathrm{v}-57$.

41. Antonio Samper, La república argentina vista por un colombiano (Buenos Aires: Kidd y Cía. Limitada, 1891) 3.

42. AGN, Bogotá, Ministerio de Relaciones Exteriores, Diplomática y Consular, Consulado de Colombia en Argentina-Buenos Aires. 1872-1910, caja 43, carpeta 110, 88-88v.

43. Victor Bulmer-Thomas, The Economic History of Latin America Since Independence (New York: 
the Argentinian paper currency system and the crises it had created. ${ }^{44}$ In Colombia, paper currency was also in widespread use; thus, the Argentinian crisis potentially presaged a disastrous outcome. In fact, after offering a detailed explanation and his point of view about the causes of this crisis and the solutions taken to resolve it, Samper stated: "I fervently hope that Argentina will find the formula for her wellbeing, and I present its example to my country to learn from it, assuring to you [Minister of Foreign Affairs] my belief that Argentina has not progressed thanks to paper currency, as some argue, by obfuscation, but in spite of it." ${ }^{45}$ Likewise, in May 1890 the Colombian newspaper El Porvenir published a study of the paper money system that, drawing from the Argentinian experience, claimed: "The danger to which we have alluded comes from the temptation offered by the incentive of spending accompanied by the ease of dealing with new issues of paper currency, which, converted into an ordinary resource, leads to catastrophes like the one that threatens the Argentine Republic today." ${ }^{46}$ If Colombian newspapers such as El Porvenir could publish such studies, it was because intellectuals like Isaacs and the two Samper had already granted Colombians access to global information, mostly from the Southern Cone.

At the turn of the century, and following in Jorge Isaacs's footsteps, the Colombian Consul in Chile, Clímaco Valdez, also channeled useful information back to Colombia. In October 1900, Valdez reported that he was about to ship to Colombia "37 volumes of state reports, statistics, fiscal budgets, general account of the treasury, etc., some of which were requested by that Ministry of Finance, and others that I have judged of interest for our public administration." ${ }^{77}$ A month later, he wrote correcting the former figure, and informed that he had shipped 68 Chilean books to Colombia, 47 of which were "bulletins of laws and government decrees." ${ }^{48}$ The package also included a "mining bill," commercial statistics,

Cambridge University Press, 2003) 71; Oscar Camilión, The Argentine Crisis (New York: Council on Foreign Relations, 1990); Roberto Cortés Conde, "The Growth of the Argentine Economy, c. 1870-1914," The Cambridge History of Latin America c. 1870 to 1930, vol.V, ed. Leslie Bethell (Cambridge: Cambridge University Press, 1986) 344-47; AHCA, Buenos Aires, Diplomática y Consular, Consulado General de Colombia, caja 444, 1890, ff. 64-69v.

44. "La crisis argentina. Sus causas y desarrollo," El Correo Nacional (Bogotá) December 16, 1890: 2; "Como marcha la Argentina," La República (Bogotá) February 6, 1894: 1; "Papel moneda," La República (Bogotá) March 15, 1894: 1; “República Argentina,” La República (Bogotá) February 3, 1891: 3; “El problema argentino," El Correo Nacional (Bogotá) February 12, 1891: 2; "República Argentina," El Correo Nacional (Bogotá) February 15, 1891: 2.

45. AHCA, Buenos Aires, Diplomática y Consular, Consulado General de Colombia, caja 444, 1890, f. 69v.

46. Miguel Samper, Crisis monetaria. Artículos publicados en "El Relator", precedidos de fragmentos del folleto titulado Banco Nacional (1880) y del titulado Nuestra circulación monetaria (1890) (Bogotá: Imprenta de La Nación, 1892) 52-53.

47. AGN, Bogotá, Ministerio de Relaciones Exteriores, Diplomática y Consular, Transferencia 2, Consulado de Colombia en Chile, 1899-1902, t. 44, f. 54.

48. AGN, Bogotá, Ministerio de Relaciones Exteriores, Diplomática y Consular, Transferencia 2, 
reports on foreign relations and on "Culto y Colonización," "astronomical observations of the observatory of Santiago de Chile," a study of "cholera prophylaxis," reports on "telegraphs and post office," and a variety of volumes on "education and instruction." 49

Given the rapid economic growth in neighboring countries, Colombian intellectuals and statesmen such as Jorge Isaacs, José María Samper, Antonio Samper, and Clímaco Valdez sought not only to learn from them, but also to give their support to commercial and literary conventions, which would allow a faster and more efficient examination of republics in the region through the collection and shipment of useful printed materials. During the second half of the nineteenth century, the Colombian diplomatic corps in Latin American countries played a key mediating role by collecting and sending to Colombia a selection of useful publications. They sought to identify models from Latin American countries that were directly adaptable to Colombia's unique circumstances. However, they also looked to neighboring countries via mediators established in the United States and Europe.

\section{Reporting from Paris}

By the 1880s, cosmopolitan Paris had become the most important international meeting point for Latin Americans. ${ }^{50}$ In 1887, Colombian statesman Carlos Holguín (1832-1894) stated that Paris was "virtually [...] the capital of Latin America, whose children, if living fraternally, will be able to consolidate and put on track their common interests." ${ }^{51}$ In fact, the Latin American population residing in Paris grew from 4,000 in the 1870 s to 6,000 in 1900 , without counting many other temporary visitors. ${ }^{52}$ Many intellectuals, artists, politicians, and businessmen from all over Latin America worked diligently on getting to know each other in the City of Light, promoting their countries and sharing their ideas about material and intellectual progress. Most of this work was carried out by establishing associations, such as the Sociedad Politécnica de Colombia, the Sociedad de la Unión Latinoamericana, the Sociedad América, and the Sociedad Latino-Americana "Biblioteca Bolívar." Most of these were created during the 1870 s, and their founding members included Colombians José Tomás Henao, Jorge Enrique Delgado, José María Torres Caicedo, Ignacio Gutiérrez Ponce, and Ramón Santo Domingo Vila. ${ }^{53}$

Consulado de Colombia en Chile, 1899-1902, t. 44, f. 70.

49. AGN, Bogotá, Ministerio de Relaciones Exteriores, Diplomática y Consular, Transferencia 2, Consulado de Colombia en Chile, 1899-1902, t. 44, ff. 68-68v.

50. Jens Streckert, Die Hauptstadt Lateinamerikas: eine Geschichte der Lateinamerikaner im Paris der Dritten Republik (1870-1940) (Cologne: Böhlau, 2013) 37-43; Jens Streckert, "Latin Americans in Paris, 1870-1940:A Statistical Analysis," Jahrbuch für Geschichte Lateinamerikas 49 (2012): 181-204.

51. “Unión Latino-Americana,” La Estrella de Panamá (Panama) October 22, 1887: 4.

52. Streckert, Die Hauptstadt 75-76.

53. Martínez 153-54. 
The fact that they were living in Paris does not mean that they looked to North Atlantic models exclusively. Intellectuals residing in Europe, such as Colombia's Adriano Páez, strived to ensure that official and informal data on Latin American countries would reach Paris and, once gathered and selected carefully, return to Latin America (mostly) in the form of periodicals.

Adriano Páez (1844-1892) was appointed Consul of Colombia in Le Havre toward the end of 1870. Besides building up intellectual networks and contributing to the leading journals of Madrid, Paris, Florence, and London, Páez founded Revista Latino-americana, a journal published in 1874 in Paris and written in both French and Spanish. It was the first newspaper published by a Colombian in the City of Light. ${ }^{54}$ By inviting a myriad of Latin American contributors to his journal, Páez aimed to disseminate knowledge about Latin America in Europe, as well as to circulate useful ideas back in the Americas. The Revista's goal was twofold: to "defend" in Europe "the interests of the continent of Columbus" and to bruit widely everything "useful to [Latin] America". ${ }^{55}$ Aware of the importance of informing Latin Americans about their countries' history and reflecting on their progress, Páez openly "begged" Latin American newspapers to "examine and discuss" the ideas put forward in his journal. ${ }^{56}$ This periodical included articles on relations between Europe and Latin America as well as on Latin American countries' past history and contemporary affairs. These works focused on specific stories of technology spillover, such as the introduction of railroads, encouraging immigration, the debates regarding the sugar industry, and guidelines for adapting relatively new economic enterprises like sericulture. This periodical also regularly published lists of books by Latin American writers as well as news of politics, economics, and some European countries. Overall, a frequent reader of Revista Latinoamericana would not have missed out on relevant information about Europe's and Latin America's signs of progress.

Revista Latino-americana circulated widely in Colombia and in Latin America; the Colombian government alone allocated 1,800 Colombian pesos to pay for 300 subscriptions of this journal out of its budget for the fiscal year 1874-1875. ${ }^{57}$ Moreover, it was distributed in seven Colombian cities and presented as a gift to presidents of Latin American countries, as well as to the main newspapers and libraries within the American continent. ${ }^{58}$ Before returning to his home country in 1876, Páez managed to publish four volumes of nearly 1,200 pages in total. Later, the number of Latin American publications in Paris would increase under the influence of societies like the Sociedad Latino-Americana "Biblioteca Bolívar,"

54. Martínez 149.

55. Adriano Páez, “Introducción,” Revista Latino-americana 1 (Paris) 1874: 4-5.

56. Páez 5.

57. Memoria del Secretario del Tesoro dirijida al Presidente de la Unión para el Congreso de 1874 (Bogotá: Imprenta de Gaitán, 1874) viii.

58. Martínez 149. 
which was formed in Paris to celebrate the first centenary of Simón Bolivar's birth. ${ }^{59}$ Some Colombian intellectuals such as Ignacio Gutiérrez Ponce (18501942) were prominent figures in this society. ${ }^{60}$

Seeking to publicize American countries abroad and to strengthen bonds among Latin Americans, the "Biblioteca Bolivar" operated as an independent library from 1883 to 1890 . In 1885, the library had already collected 3,000 volumes of official publications and original works, most of them by Latin American authors. ${ }^{61}$ In 1889, the library's chairman, Ignacio Gutiérrez Ponce, published the library's first catalog, which was divided into fourteen categories: "law and legislation, history, literature, philosophy and religion, economics and finance, geography, navigation, travel, philology and pedagogy, science, arts, commerce and industry, maps, and periodicals." ${ }^{2}$ Toward the end of the 1880 s, this library became perhaps the largest specialized collection on Latin America in Paris (and thus in the world), as many Latin American newspapers reported. ${ }^{63}$ However, lacking consistent benefactors to properly maintain it, the Sociedad Latino-Americana "Biblioteca Bolivar" donated the library to the French government, which had been the original idea. It was annexed to the Institut de France's Bibliothèque Mazarine in 1890, remaining accessible to visitors from around the world and mainly to Paris's Latin American population. ${ }^{64}$

Members of the "Biblioteca Bolívar"- - such as Uruguayan Pedro S. Lamas, who was elected the Society's first vice-president-contributed notably to the circulation of ideas of Latin America from Paris. ${ }^{65}$ Besides publishing books and articles promoting Latin American countries, particularly Argentina, Lamas was the editor of Revue Sud-Américaine from 1882 to $1890 .{ }^{66}$ This was a fortnightly

59. Martínez 153-54; Ignacio Gutiérrez Ponce, Reminiscencias de vida diplomática, 1879 a 1923, y Crónicas de mi hogar en la época colonial, 1536 a 1816 (London / Tonbridge: Whitefriars Press, 1926) 19.

60. Martínez 154; Gutiérrez Ponce 105.

61. Gutiérrez Ponce105.

62. Gutiérrez Ponce 105.

63. Jacyn, "Revista. París, Diciembre 5 de 1885," El Siglo Diez y Nueve (Mexico) January 6, 1886: 1; "París. Sociedad Latino-Americana. 'Biblioteca Bolívar," El Heraldo (Cochabamba) August 3, 1886: 2; "Cartas europeas. París, Octubre 28 de 1886," El Heraldo (Cochabamba) January 15, 1887: 2; “Unión Latino-Americana," La Estrella de Panamá (Panama) October 22, 1887: 4; Jacyn, “Revista. París, Mayo 1 de 1888," El Siglo Diez y Nueve (Mexico) May 22, 1888: 2; “Asociación de la Biblioteca Bolívar," El Heraldo (Bogotá) July 16, 1890: 3; Rafael Bermúdez de Castro, "Reseña histórica sobre las bibliotecas antiguas y modernas de Europa y América," Pabellón de Honduras (Tegucigalpa) October 13, 1900: 2.

64. Gutiérrez Ponce 106.

65. Sociedad Latino-Americana "Biblioteca Bolívar," "Estatutos de la Sociedad Latino-Americana 'Biblioteca Bolívar.' 21 rue de Grammont-Paris," Anales de la Instrucción Pública en los Estados Unidos de Colombia (Bogotá) December 1883: 408-413.

66. Pedro S. Lamas, Objetivos y resultados de mis trabajos en Europa en favor de la República Argentina (1882-1890 (Paris:V. Goupy y Jourdan, 1890). 
periodical until 1888, when it became a weekly magazine. Several Latin American governments and private entrepreneurs used it to showcase their progress and trade statistics. Moreover, many chronicles about Latin American and European current affairs and specific studies about Latin American countries were published. In addition, each edition included financial and economic reviews, bibliographical information, and useful announcements. Reporting commercial and cultural possibilities of Latin American countries, the Revue Sud-Américaine main targeted a European readership. However, it also aimed to strengthen ties among Latin Americans. This publication circulated widely, allowing interested people to improve their knowledge of Latin America.

Revue Sud-Américaine was available through subscription and purchases at post offices. It was also available free of charge in some of Paris' reading rooms, public establishments, and trade unions. ${ }^{67}$ Although Colombia only had a few direct distributors of international newspapers, publications such as the Revue Sud-Américaine circulated widely and were quoted in some Colombian publications. ${ }^{68}$ In fact, Colombia was the country with the most direct agents of this journal. In 1883, while countries such as Argentina, Brazil, Chile, Ecuador, Guatemala, Mexico, Nicaragua, Peru, Salvador, Uruguay, and Venezuela had one agent, the journal reported ten different ones in Colombia, which shows the efforts of some Colombians to spread ideas of Latin America in their home country. ${ }^{69}$

Colombian periodicals enriched their contents by incorporating information about Latin America that circulated widely in Paris. While in 1870 only four Parisian publications addressed topics related to Latin America, and the access to news depended on the importation of Latin American newspapers, since the proclamation of the French Third Republic in 1870 the number of publications about Latin America grew, many of them directed and edited by Latin Americans living in the French metropolis. ${ }^{70}$ Some examples of them were El Américano: ilustrado, politico y literario (1872-1874), Revista Latino-americana (1874), Europa y América. Revista quincenal ilustrada de literatura, artes y ciencias (1880-1895), Le Brésil. Courrier de l'Amérique du Sud (1881-1922), La Estrella de Chile. Órgano de la colonia chilena en Europa (1891), América en París. Revista quincenal (1891-1892), La République Cubaine. La República Cubana (1896-1897), and Revue Sud-Américaine (1882-1890,1913). ${ }^{71}$ Together, these periodicals provided the foundation for a thriving intellectual community and an exchange of ideas among Latin American intellectuals abroad. In other words, these papers were important for spreading — and contributing to - a regional transfer of knowledge among Latin American countries.

67. Streckert 271.

68. Martínez 79; Enrique Álvarez, La crisis económica (Bogotá: Imprenta de La Luz, 1886); Gutiérrez Ponce.

69. Revue Sud-Americaine (Paris) April 15, 1883: 468.

70. Rojas 255.

71. Rojas $255-56$. 
Bookstores also facilitated the circulation of Latin American ideas in Colombia. ${ }^{72}$ One of the most influential bookstores in Bogotá was Librería Torres Caycedo, named after José María Torres Caicedo (1830-1889), a member of the "Biblioteca Bolivar" and esteemed Colombian who "was the protector and mentor of all South Americans, and Colombians in particular, who arrived in Paris."73 According to the Colombian intellectual Lázaro María Pérez, this was "the best, internationally connected bookstore in the country"; ${ }^{74}$ it built up a Latin American collection, resulting from the network of exchanges its owner weaved with Latin American booksellers, mainly from Argentina, Chile, Nicaragua, and Mexico. Among other connections, the relationship between Pérez and Chilean Roberto Miranda was key; it lasted for about a decade and led to the circulation of original Chilean manuscripts like Exposición razonada y estudio comparativo del Código Civil Chileno (1868) and Código civil ante la Universidad (1871) by Jacinto Chacón in Colombia. ${ }^{75}$ Aiming to identify appropriate models for Colombia's unique circumstances from neighboring countries, books on Latin American legal institutions were among the critical materials circulated by intellectuals in Colombia toward the end of the century. The models that Colombians drew from Chile included its Civil Code. Although this was adapted separately by Colombia's states during the federative era (1863-1886), it was widely adopted by the whole territory of Colombia by Law 86 of 1887, immediately after the Constitution of 1886 established a centralist government. Although it was not an identical copy, Chile's Code served as a mediated base. ${ }^{76}$

Besides selling books, bookstores also offered subscriptions to periodicals from around the world. Although the first modern bookstore in Bogotá was opened by Juan Simonnot in 1851, offering subscriptions to two of the most influential European publications for Latin Americans, Correo de Ultramar and El Eco de Ambos Mundos, Librería Torres Caycedo promoted subscriptions to a wide variety of Latin American periodicals, such as Revue Sud-Américaine and Revista del Mundo Latino from Paris, and El Educador Popular, La Industria, El Ateneo, and La América Ilustrada from New York. ${ }^{77}$ This access via subscription to international periodicals stemmed from the efforts of many intellectuals - not only in the Southern Cone and Europe, but also in the US - during the second half of the nineteenth century.

72. Juan David Murillo Sandoval, “La aparición de las librerías colombianas. Conexiones, consumos y giros editoriales en la segunda mitad del siglo XIX," Historia Crítica 65 (2017): 49-69. DOI: 10.7440/histcrit65.2017.03.

73. José María Quijano Wallis, Memorias autobiográficas, histórico-políticas y de carácter social (Roma: Tipografia Italo-Orientale, 1919) 172.

74. Murillo 56; Martínez 64.

75. Murillo 57.

76. Fernando Vélez, Datos para la historia del derecho nacional (Medellín: Imprenta del Departamento, 1891) 79.

77. Murillo 56; Martínez 64; “Anuncios. La Librería Torres Caycedo,” El Conservador (Bogotá) October 9, 1883: 1. 
Moreover, bookstores circulated publications informing Colombians about Latin American countries' signs of progress as well as deliberating on useful global developments and making suggestions for action. Chief among other stimulating works were Eustacio Samtamaría's two volumes of Conversaciones familiares (whose chapters were originally published as newspaper articles) and Father Federico Cornelio Aguilar's publications, mainly his comparative masterpiece entitled Colombia en presencia de las repúblicas Hispano-Americanas. ${ }^{78}$ It is worth noting that Aguilar was highly regarded in Colombia because "through his constant correspondence with the press [while living 30 years abroad], accumulating hundreds of articles, he made brother nations known to us," as the Colombian intellectual Arturo Quijano wrote in a posthumous homage paid to Aguilar in $1922 .{ }^{79}$ Both Santamaria and Aguilar devoted years to observation and analysis of the political and economic conditions of many different peoples around the world, including Latin American nations. They put into writing their considerations, aiming to provide Colombians with insights into global affairs and, ideally, to raise awareness in Colombia of a variety of opportunities to thrive on the world stage. These works could be the subject of an entire article, but for reasons of space we cannot analyze them in detail here.

\section{Conclusions}

No good reasons seem to exist to continue echoing oft-uncontested assumptions about physical, let alone intellectual isolation in Colombia toward the end of the nineteenth century. As ideas could move more easily and inexpensively than people, Colombian intellectuals and statesmen fostered the circulation of global ideas, including but not limited to Latin America's news and printed materials via the Southern Cone, Paris, and New York to Colombia. They circulated firsthand information and negotiated treaties and the official exchange of publications while on diplomatic postings to countries such as Argentina, Chile, and France. In short, they promoted a movement of ideas that was key to expanding intra-Latin American mutual knowledge and identifying appropriate models for Colombia's particular circumstances. In the form of periodicals, books, and manuscripts, useful knowledge of Latin America circulated widely in Colombia during the second half of the nineteenth century, with increasing dynamism and numbers of publications since the 1870 s.

78. Eustacio Santamaría, Conversaciones familiares sobre industria, agricultura, comercio, etc., etc., etc., 3 vols. (Havre: A. Lemale Aîné, 1871); Federico Cornelio Aguilar, Colombia en presencia de las repúblicas Hispano-Americanas (Bogotá: Imprenta de Ignacio Borda, 1884); Federico Cornelio Aguilar, "Ligero estudio sobre las minas de Méjico y Colombia," Anales de la Instrucción Pública (Bogotá) 1884; Federico Cornelio Aguilar, Último año de residencia en México (Bogotá: Imprenta de Ignacio Borda, 1885).

79. Arturo Quijano, “Cónsules de Ideas,” El Gráfico 622 (Bogotá) November 1922: 350. 
If intra-Latin American interactions were not as visible as the exchanges with the North Atlantic it was not for reasons of objective isolation. In fact, most of the trade routes were well established across the Atlantic basin, making people "hungry" for Latin American and international publications willing to look for circulation among the existing routes. In so doing, many Colombians managed to acquire printed materials from within Latin America and sought eagerly to extend their reach to their fellow citizens. By circulating global ideas, some intellectuals, statesmen, and interested Colombians in general sought to provide their compatriots with relevant information and compelling reasons to raise awareness about Colombia's place in the world relative to other Latin American countries. Their aim was ideally to push them toward actions intending to reach higher levels of material and intellectual progress. Disregarding the oft-blamed topographic and infrastructural hindrances, they managed to interconnect Colombians with Latin Americans and with the world. Colombians could form mental images of other Latin American countries as much as they did of countries in the North Atlantic because global publications circulated widely in their homeland, mainly after intellectuals and statesmen managed to overcome infrastructure difficulties via intermediaries, official conventions, and publication exchanges.

This article has shown that the production and circulation of ideas stand as relevant as well as productive historical phenomena that allow researchers to couple research agendas that are often divorced in the form of intellectual, diplomatic, international relations, and economic histories. Further analyses intertwining such historical subjects would contribute to offering fresh insights and reinterpretations to better understand the history of Latin America over the long term.

\section{References}

\section{Manuscripts}

Archivo Histórico de la Cancillería Argentina, Buenos Aires (AHCA)

Diplomática y Consular, Consulado General de Colombia

Archivo General de la Nación, Bogotá (AGN)

Ministerio de Relaciones Exteriores, Diplomática y Consular

\section{Printed}

Aguilar, Federico Cornelio. Colombia en presencia de las repúblicas Hispano-Americanas. Imprenta de Ignacio Borda, 1884.

. Último año de residencia en México. Bogotá: Imprenta de Ignacio Borda, 1885.

Álvarez, Enrique. La crisis económica. Bogotá: Imprenta de La Luz, 1886.

Estadística comercial de la República de Chile correspondiente al año de 1873.Valparaíso: Imprenta del Mercurio, 1874.

Estadistica del comercio exterior $i$ de cabotaje $i$ de los demas ramos relacionados con la ha- 
cienda nacional, correspondiente al año de 1869 a 1870. Bogotá: Imprenta de Gaitán, 1871.

Gutiérrez Ponce, Ignacio. Reminiscencias de vida diplomática, 1879 a 1923, y Crónicas de mi hogar en la época colonial, 1536 a 1816. London / Tonbridge: Whitefriars Press, 1926.

Lamas, Pedro S. Objetivos y resultados de mis trabajos en Europa en favor de la República Argentina (1882-1890). Paris:V. Goupy y Jourdan, 1890.

Memoria del Secretario de lo Interior i Relaciones Esteriores al Congreso de Colombia. Bogotá: Imprenta de Medardo Rivas, 1870.

Memoria del Secretario de lo Interior i Relaciones Esteriores al Congreso de Colombia. Bogotá: Imprenta de Medardo Rivas, 1871.

Memoria del Secretario de lo Interior i Relaciones Esteriores al Congreso de Nacional de 1872. Bogotá: Imprenta de Medardo Rivas, 1872.

Memoria del Secretario del Tesoro dirijida al Presidente de la Unión para el Congreso de 1874. Bogotá: Imprenta de Gaitán, 1874.

Memoria del Secretario de Relaciones Exteriores dirigida al presidente de la Unión Para el Congreso de 1885. Imprenta de Vapor de Zalamea Hermanos, 1885.

Nelson, Wolfred. Five Years at Panama the Trans-Isthmian Canal. London: Sampson Low, Marston, Searle \& Rivington, 1891.

Oficina de Estadística Nacional. Estadística de Colombia. Bogotá: Imprenta de Medardo Rivas, 1876.

Paz, Manuel María. Itinerario general de distancias acompañado de varios datos geográficos $y$ de un mapa de la República de Colombia. Paris: A. Lahure, 1890.

Quijano Wallis, José María. Memorias autobiográficas, histórico-políticas y de carácter social. Roma:Tipografia Italo-Orientale, 1919.

Samper, Antonio. La república argentina vista por un colombiano. Buenos Aires: Kidd y Cía. Limitada, 1891.

Samper, Miguel. Crisis monetaria. Artículos publicados en "El Relator", precedidos de fragmentos del folleto titulado Banco Nacional (1880) y del titulado Nuestra circulación monetaria (1890). Bogotá: Imprenta de La Nación, 1892.

Santamaría, Eustacio. Conversaciones familiares sobre industria, agricultura, comercio, etc., etc., etc. 3 vols. Havre: A. Lemale Aîné, 1871.

Uribe, Antonio José. Ed. Anales diplomáticos y consulares de Colombia.Volume 2. Bogotá: Imprenta Nacional, 1901.

Vélez, Fernando. Datos para la historia del derecho nacional. Medellín: Imprenta del Departamento, 1891.

\section{Newspapers and journals}

Anales de la Instrucción Pública (Bogotá) 1884.

Anales de la Instrucción Pública en los Estados Unidos de Colombia (Bogotá) 1883, 1888. 
Anales de Jurisprudencia. Órgano de la Sociedad Colombiana de Jurisprudencia (Bogotá) 1896-1897, 1904.

Colombia Ilustrada (Bogotá) 1890.

El Catolicismo (Bogotá) 1860.

El Conservador (Bogotá) 1883.

El Correo Nacional (Bogotá) 1890-1891.

El Gráfico (Bogotá) 1922.

El Heraldo (Bogotá) 1890.

El Heraldo (Cochabamba) 1886-1887.

El Siglo Diez y Nueve (Mexico) 1886, 1888.

La Estrella de Panamá (Panama) 1887.

La República (Bogotá) 1891, 1894.

Pabellón de Honduras (Tegucigalpa) 1900.

Revue Sud-Americaine (Paris) 1883.

Revista Latino-americana (Paris) 1874.

\section{Bibliography}

Asociación de Bibliotecas Nacionales de Iberoamérica. Coord. Historia de las bibliotecas nacionales de Iberoamérica: pasado y presente. Mexico City: Universidad Nacional Autónoma de México, 1995.

Bulmer-Thomas, Victor. The Economic History of Latin America Since Independence. New York: Cambridge University Press, 2003.

Camilión, Oscar. The Argentine Crisis. New York: Council on Foreign Relations, 1990.

Castillero Reyes, Ernesto de Jesús. El Ferrocarril de Panamá y su historia. Panama: Imprenta Nacional, 1932.

Cortés Conde, Roberto. "The Growth of the Argentine Economy, c. 1870-1914." The Cambridge History of Latin America c. 1870 to 1930. Volume V. Ed. Leslie Bethell. Cambridge: Cambridge University Press, 1986.

Cribelli, Teresa. Industrial Forests and Mechanical Marvels: Modernization in Nineteenth-Century Brazil. New York: Cambridge University Press, 2016.

Guitarte, Guillermo L. Ed. Cartas desconocidas de Miguel Antonio Caro, Juan María Gutiérrez y Ezequiel Uricoechea. Bogotá: Instituto Caro y Cuervo, 1962.

Henríquez Ugreña, Pedro. Historia cultural y literaria de la América Hispánica. Madrid: Verbum, 2006.

Loaiza Cano, Gilberto. Poder letrado. Ensayos sobre historia intelectual de Colombia, siglos XIX y XX. Cali: Universidad del Valle, 2014.

Londoño-Vega, Patricia. Religion, Culture, and Society in Colombia: Medellín and Antioquia, 1850- 1930. Oxford: Oxford University Press, 2002.

Maiguashca, Juan. "Historians in Spanish South America: Cross-References between Centre and Periphery." The Oxford History of Historical Writing. 1800-1945.Volume 4. Ed. Stuart Macintyre and others. Oxford: Oxford University Press, 2011. 
Marichal, Carlos and Alexandra Pita. "Algunas reflexiones sobre la historia de los intelectuales/diplomáticos latinoamericanos en los siglos XIX y XX: Introducción al dossier Intelectuales y diplomacia en América Latina." Revista de Historia de América 156 (2019): 97-123. DOI: 10.35424/ rha.156.2019.235.

Martínez, Frédéric. El nacionalismo cosmopolita: la referencia europea en la construcción nacional en Colombia, 1845-1900. Bogotá: Banco de la República / Instituto Francés de Estudios Andinos, 2001.

Matthew C. Mirow. Latin American Law. A History of Private Law and Institutions in Spanish America. Austin: University of Texas Press, 2004.

Murillo Sandoval, Juan David. "La aparición de las librerías colombianas. Conexiones, consumos y giros editoriales en la segunda mitad del siglo XIX." Historia Crítica 65 (2017): 49-69. DOI: 10.7440/histcrit65.2017.03.

Preuss, Ori and Juan Pablo Scarfi. "Relaciones internacionales, identidades colectivas y vida intelectual en América Latina, 1810-1945: Presentación.” Revista Complutense de Historia de América 39 (2013): 15-21.

Restrepo, Jorge Alberto and Manuel Rodríguez. "La actividad comercial y el grupo de comerciantes de Cartagena a fines del siglo XIX.” Estudios Sociales 1 (1986): 43-109.

Richmond, Douglas W. Conflict and Carnage in Yucatán: Liberals, the Second Empire, and Maya Revolutionaries, 1855-1876. Tuscaloosa: University of Alabama Press, 2015.

Rodríguez Torres, Álvaro. Reseña histórica de la Biblioteca Nacional de Colombia. Bogotá: Colcultura, 1994.

Rojas, Daniel Emilio. "Los latinoamericanos de París en el cambio de siglo. Sobre Die Hauptstadt Lateinamerikas (2013), de Jens Streckert." Colombia Internacional 87 (2016): 243-259. DOI: 10.7440/colombiaint87.2016.10.

Rubiano Muñoz, Rafael. Prensa y tradición: La imagen de España en la obra de Miguel Antonio Caro. Medellín: Siglo del Hombre Editores, 2011.

Safford, Frank and Marco Palacios. Colombia: Fragmented Land, Divided Society. New York: Oxford University Press, 2002.

Sommer, Doris. Foundational Fictions: The National Romances of Latin America. Berkeley / London: University of California Press, 1991.

Streckert, Jens. Die Hauptstadt Lateinamerikas: eine Geschichte der Lateinamerikaner im Paris der Dritten Republik (1870 - 1940). Cologne: Böhlau, 2013. . "Latin Americans in Paris, 1870-1940: A Statistical Analysis." Jahrbuch für Geschichte Lateinamerikas 49 (2012): 181-204.

Tenorio-Trillo, Mauricio. Mexico at the World's Fairs: Crafting a Modern Nation. Berkeley: University of California Press, 1996. 